\title{
Hazardous Waste Management Situation in Bangladesh: An Assessment of Existing Legal Frameworks and Challenges through Working from Home
}

\section{Mohammad Abdul Hannan and Osaro Aigbogun}

To Link this Article: http://dx.doi.org/10.6007/IJARBSS/v11-i10/11273

DOI:10.6007/IJARBSS/v11-i10/11273

Received: 05 August 2021, Revised: 27 August 2021, Accepted: 19 September 2021

Published Online: 04 October 2021

In-Text Citation: (Hannan \& Aigbogun, 2021)

To Cite this Article: Hannan, M. A., \& Aigbogun, O. (2021). Hazardous Waste Management Situation in Bangladesh: An Assessment of Existing Legal Frameworks and Challenges through Working from Home. International Journal of Academic Research in Business and Social Sciences, 11(10), 24-43.

Copyright: (c) 2021 The Author(s)

Published by Human Resource Management Academic Research Society (www.hrmars.com) This article is published under the Creative Commons Attribution (CC BY 4.0) license. Anyone may reproduce, distribute, translate and create derivative works of this article (for both commercial and non-commercial purposes), subject to full attribution to the original publication and authors. The full terms of this license may be seen at: http://creativecommons.org/licences/by/4.0/legalcode

Vol. 11, No. 10, 2021, Pg. 24 - 43

Full Terms \& Conditions of access and use can be found at http://hrmars.com/index.php/pages/detail/publication-ethics 


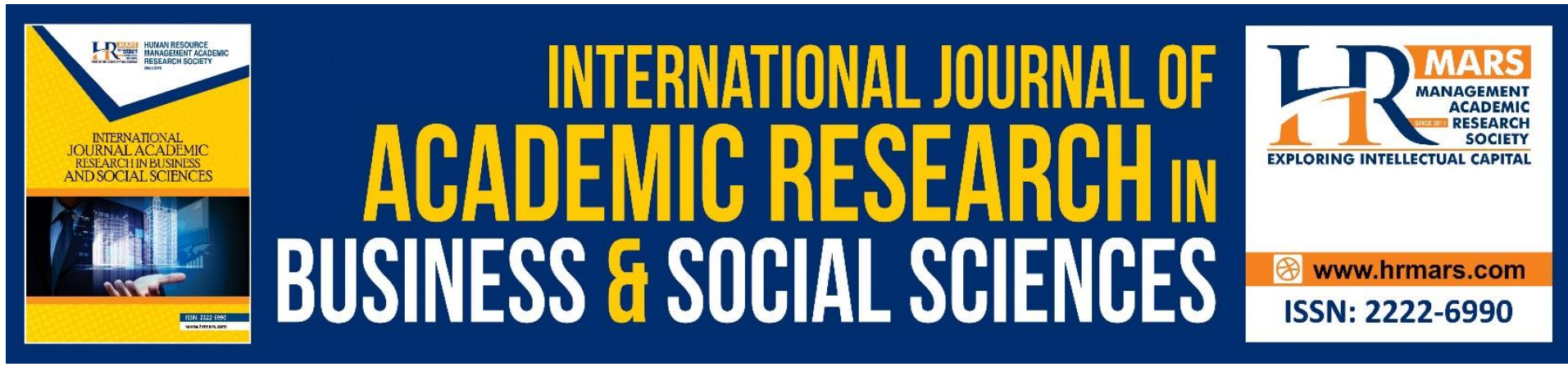

\title{
Hazardous Waste Management Situation in Bangladesh: An Assessment of Existing Legal Frameworks and Challenges through Working from Home
}

\author{
Mohammad Abdul Hannan ${ }^{1}$ and Dr. Osaro Aigbogun ${ }^{2}$ \\ ${ }^{1}$ Assistant Professor, Department of Law, BGC Trust University Bangladesh and PhD \\ Researcher, Binary University, ${ }^{2}$ Senior Lecturer, Binary University of Management \& \\ Entrepreneurship, Malaysia
}

\begin{abstract}
Hazardous waste has become one of the most alarming threats to the environmental as well as socio-political aspects of Bangladesh. Sustainable waste management is a longer lasting challenge for the developing countries like Bangladesh. In addition to this, because of inadequacy of work force, antique waste management system, technical scarcity and overall corruption the government specially the concerned local government of the municipality is facing the issue rampant and threatening. Notwithstanding that the government ratified international Basel Convention, 1989 and enhanced diversified legal policies to dispose and recycle the hazardous wastes. Nonetheless, gigantic growing extent of wastes is posing dangerous warning to the existing waste management and disposal processes. Additionally, the sound management of wastes and environmental hazards were in less emphasis and least studied previously whereas nowadays the government and relevant stakeholders are considering this issue with importance to preserve the human health and nature where specific sectoral and fruitful working systems are initiated. However, the most acceptable methods i.e. recycling, reduction and reuse are not being applied effectively by the responsible authorities of the government. Hence, the sustainability of waste managing is ended in smoke and being more complicated. In the study, conceptualization of electronic waste, environmental hazards, waste generation process are stated cognitively. At the same time the study ventures on the conceptual aspects of both global and national prevalent methods for sustainable waste management. Moreover, integrative literature review is conducted to find out the limitations of the prevailing legal policies of the government are elaborated practically and recommended ways to develop the efficient and sustainable waste management systems to get rid of the perilous consequences of hazardous wastes. During the pandemic crisis it is found to be more challenging as working from home is a pre dominant factor in the new norm.
\end{abstract}

Keywords: Sustainable Hazardous Waste Management, Basel Convention, Environmental perils, Existing policies, Work From Home, Pandemic. 


\section{Introduction}

Sustainable Waste Management has become a longer lasting problem in Bangladesh because of lack of proper application of management policies available nationally and internationally. At present the waste management in urban area particularly in Dhaka the problem is being very challenging and serious. The existing disposal methods are being futile despite the local Government authority is attempting to ameliorate waste collection systems. The overall system is creating threat for the city dwellers as the services of City Corporation are not adequate to meet the expectations (Hossain et al., 2021). Hence, to ensure hygienic life of city dwellers the local government is supposed to enhance the sustainable hazardous waste in compliance with the global policies. The study will emphasize on how the institutional mechanisms of solid waste management are being applied to reduce suffering of people in Dhaka Bangladesh. The strategic capacity of Dhaka city for the management of solid waste has been analyzed in this study to evaluate how effectively they are contributing as the city is over-burdened with hazardous wastes. It is high time the Dhaka city waste management authority introduced the solid waste management system whereby the city will be get rid of curse of excessive challenges of hazardous wastes. More significantly, Solid waste management services of Dhaka City Corporation (DCC) is not playing effective role strategically. Hence, the necessity of developing waste management process is drastically beyond description. Furthermore, gigantic disposal of medical waste is deteriorating detrimental impacts on the environment as well as human health in the pandemic of covid 19. The challenges of management of diversified waste more severely in the pandemic situation are worsening to cause misery of the urban people of Bangladesh. Consequently, the study ponder over exact processes of waste managing systems i.e. recycling, collection, treatment, storage, transportation, reuse and disposal etc so that existing policy frameworks of overall system can be ameliorated. As Bangladesh is a developing country with huge density population particularly in Dhaka city, so municipal solid waste (MSW) management systems are not up to the mark rather becoming alarming not only for human health but also for environmental nature. Azad (2017a) mentioned that in Bangladesh recent waste generation rate is almost 22.4 million tones every year. The rate is increasing day by day and it is presumed that that the increasing rate will be 47, 064 tonnes per day by 2025. Additionally, the collection rate of waste in major cities of Bangladesh especially is not more than $37 \%$ which is alarming. When the waste will not be collected properly, then mismanagement in disposal of waste seriously causes both environmental and human health perils. UNEP report (2020a) states that during COVID-19 the challenges of MSW management in the developing countries like Bangladesh become more serious and posing threats for public health and environment. Additionally, the health care waste is posing severe impact on health protection. Additionally, the study also focus on the management of municipal solid waste (MSW) and healthcare wastes particularly generated in large quantities during the pandemic including wastes of household and quarantine places for suspected and confirmed patients of COVID-19 positive where challenges of waste separation at source, discharge or handling at source, collection, transportation, recycling and final disposal are becoming very threatening. As per the World Health Organization (WHO) as a pandemic the outbreak of COVID-19 commenced in March 2020 and the number of victims is still rapidly spreading throughout the world (Hossain et al., 2020). Antara (2021a) in the report of Dhaka Tribune states that in Bangladesh effective management of medical waste during pandemic is not developed rather the process is posing threat to public health and environmental risks. Moreover, the report narrates that in Bangladesh during COVID-19 per bed medical wastes 
generation ranges from 1.63 to $1.99 \mathrm{~kg}$ every day where 654 government hospitals and 5,055 private hospitals are leading to the generation of huge amounts of biomedical waste. Additionally, as per medical journal Lancet, 206 tonnes of medical waste is generated every day in Dhaka city alone due to Covid-19.

\section{Background of the Study}

The terminology hazardous waste stands for wastes which cause severe health hazard and environmental perils consisting of liquids, solids and gases. In a nutshell, hazardous waste contains the four basic characteristics i.e. ignitability, corrosiveness, reactivity or toxicity. Hence, by analyzing overall circumstances of waste prevalent in a country are mainly divided into three categories, such as, radioactive wastes, medical wastes and no radioactive industrial liquid waste. Hazardous wastes are posing threat not only to human health but also to the environment extremely. As a consequence, the sustainability of the global environment is as stake undoubtedly. To protect health as well as environment national and international mechanisms are supposed to be developed where the systems of use, storage, handling, transportation and disposals are followed as fruitful systems of sustainable waste management. Many countries especially less developed country like Bangladesh are indifferent enough to the principles of protection of environment at the time managing hazardous waste. For the environmentally sound management of waste the purposes and roles of relevant conventions have been explored in this study so that national systems can meet challenges generated by the hazardous waste that are conducive to human health and environment protection (Hossain et al., 2021). Azad (2017b) states that in Bangladesh some effective master plans are being taken by Dhaka City Corporation with the assistance from the Japan International Corporation Agency (JICA), such as, social business enterprise and recycling programs by UNICEF have been commenced to enhance standard of managing wastes of different relevant sectors particularly industrial and medical waste in both city corporation and municipalities.

More significantly, some potential sources of hazardous wastes have been found where waste management mechanisms should be accelerated to get rid of detrimental effects. As Tania (2014) mentioned source of wastes are firstly, commercial sources: it includes wastes of garments, pharmaceuticals, company, hospital and other industry. In fact, many chemicals are used in various industries i.e. sulfuric acid, chromium, ammonium sulfate, ammonium chloride and calcium oxide. Additionally, manufacturers also applied pesticide and fungicide. Hence, various solid wastes are generated by many metallic and non metallic industries. Furthermore, medical wastes are produced by pharmaceutical industries, such as, sharp waste i.e. needles, syringes, scalpel, saw, blades, broken glass, nails etc, infectious waste i.e. pathological tissues, organs, body parts, blood and blood products, body fluids, placenta, human excreta, culture materials from laboratories etc, non infectious waste i.e. expired drugs, waste contaminated with cytotoxic drugs and leftover cytotoxic drugs and radioactive waste etc, Domestic Waste: This is another remarkable source of waste which includes contain paper, vegetable peelings, onion seed coat, broken plastic, spider net, soil dust, pieces of thread, soot, small bottles etc. Hospital and clinic wastes: These include wastes from operation theatres, laboratories which are kept in municipal bins which estimated 20 percent of hospital wastes generated in city is detrimental to human health. Finally, Tanning waste is also derived from the industrial waste that severely damage environmental balance. Additionally, the tannery industries total in Dhaka city are 149 and those industries generating 18,000 liters liquid types of wastes and solid wastes in total 115 tonnes. Tannery wastes are 
composed of various gases i.e. ammonium chloride, ammonium sulfate, chromium, sulfuric acid which are detrimental to human health causing respiratory and skin diseases and it also causes environmental damages including pollution in ecosystem and surface and ground water as well (Hossain et al., 2020). The term sustainable waste management refers to the process which is effective and conducive to environment protection, affordable and agreeable economically and also acceptable in the society. Rahman (2014) narrates that exact management of waste, storage, transportation, collection and disposal of wastes would reduce perils and also pose congenial environment for the general public of the country where the very integrated waste management would highly alleviate the detriments of human beings and environment. Razzak (2020a) states in the Daily Star that COVID-19 is making the challenges of hazardous wastes management more critical by producing large quantities of medical wastes i.e. PPE (personal protective equipment), facial tissues, gauze pieces, masks, oxygen masks, test tubes of swabs, saline bags, syringes, needles etc which are being used to treat particularly COVID patients. On April 24, 2020 the Government of Bangladesh distributed 12, 50, 000 PPE sets to hospitals which produce approximately 18, 70, 000 KG of hazardous wastes.

\section{Research Objectives}

1. To point out whether national and international legal frameworks for managing hazardous waste are being complied properly or not.

2. To examine strategic effectiveness of the existing policies of sustainable hazardous waste management.

3. To analyze the actual detrimental impacts of mismanagement of solid waste generated in leading cities of Bangladesh.

4. To review the national institutional capacity of sustainable contagious waste management system in the pandemic of COVID-19.

\section{Research Questions}

1. Do the national laws comply with international Laws on hazardous waste management?

2. How the legal mechanisms are working on management of MSW?

3. Whether existing policies are effective in managing wastes or not?

4. Does the hazardous waste keep detrimental impacts on both public health and environment?

5. How is COVID-19 creating severe impact on existing waste management process?

6. Has there been developed any special mechanisms to manage healthcare wastes generated due to COVID-19?

\section{Methodology}

This study is an analytical appreciation and critical appraisal of the current national and international mechanisms of sustainable hazardous waste management and so analysis on the legal primary sources i.e. statutes, policies, conventions, declaration, resolutions, agenda, proclamations, conventions, and decisions of court are conducted thoroughly relevant to hazardous wastes mechanisms. The methodology also comprises integrative literature review on the modes of municipal solid waste (MSW) management systems. Analytical methods are mostly conducted to generate ideas on the research theme. The literature search and data collection are an integral part of the study because they help to understand the significance of hazardous waste management for protection of human health and environment. In 
addition, study identifies the gaps that exist in the policies and strategies. For this, the study has consulted both primary and secondary materials that have been explicitly written on different types of wastes including Solid waste, medical waste and radioactive waste. The wide variety of national and international sources includes normative instruments (e.g., statutes, guidelines relevant to UNEP, Rio declaration, Basel Convention and Bamako convention on trans-boundary movement and minimization of hazardous wastes. Moreover, Integrative literature review includes country- based studies and local research publications, government documents (e.g. statistics, legislations and policy documents), academic research (e.g. books, monographs and journal articles), working papers and other publications as well as website searches on pertinent issues. Furthermore, for the comprehensive attainment of research objective the articles are reviewed from the sources of Sage, Research gate, Springer and Google Scholar including web of science as the basic source of articles for the purpose of study.

\section{Literature Review}

For the very development of integrated waste management mechanisms for the country which will be sustainable in nature, it is essential to analyze different types acceptable systems of hazardous waste management followed by the developed countries which are getting the real benefit of the process. In addition to this, the systems will be more acceptable and conducive to the human environment where every people the country will get sustainable benefits that pass across generation after generation. That recognized process include a diverse combination of waste collection, treatment and well accepted disposal systems where the optimum benefit of environment, optimization of economy and acceptability of society will be ensured. Akpon and Olukanni (2020) state that when the wastes are not treated, moved and discarded appropriately, then the wastes will be harmful where those wastes are characterized as ignitable, toxic, corrosive, radioactive and infectious. As per United States Environmental Protection Agency (USEPA) the hazardous wastes are categorized as high risk wastes i.e. chlorinated solvents and cyanide wastes, intermediate risk wastes i.e. metal hydroxide sludges and low risk wastes which are low hazard wastes. Callao et al (2019) state that Hazardous wastes have become major threat in Europe where in 2014 estimated that 95 million tons are hazardous wastes from total 2502 million tons total produced waste. Here, Wastes are managed by European Union (EU) through enacting some legislation i.e. Waste Framework Directive (WFD) which ventured to preserve the environment and human health from the detrimental impacts of hazardous wastes. WFD introduced two effective mechanisms to reduce hazardous wastes, such as, landfill and incineration. Additionally, recycling and also some recovery operations are also developed by WFD. Sawalem et al (2008) narrated that as one of developing countries Libya practiced the mechanisms for maintaining hazardous wastes that include pro environment process of generation, handling, storage and disposal of various wastes where some deficiencies as to procedures, techniques and methods were pointed out that there were sufficient scopes to improve the existing situation. Khatib et al (2009) describes that effective wastes management and essential enforcement of existing legislation to protect human and environment are mandatory and can never be denied its necessity. Moreover, development of comprehensive mechanisms to the sustainable management of wastes is mandatory in Palestine as well as in the developing countries where lack of awareness of health hazards, imperfect waste management, inadequate financial resources and improper disposal systems are the main problems found which causing barriers to overall development of the state. 
Karthikeyan et al (2018) state that hazardous wastes cause perils to human health as well as environment since hazardous wastes are characterized as corrosive, ignitable, reactive, infectious and toxic if those wastes are not properly treated, transported, stored and disposed in complying with the existing mechanisms which are not followed due to inadequate infrastructure, limitations in enforcement and ineffective waste management in India. Olukanni and Oresanya (2018) narrate that in Nigeria to ensure clean and healthy environment for human beings some effectives initiatives are initiated to reduce hazards of wastes, such as, containerization of wastes and to protect public health pro environment solid waste management, landfill gas and recycling are encouraged widely for the sustainable management of hazardous wastes. Hasan (2005) states that the urban people don't avail adequate access to door to door collection facilities by the city corporation and so various institutional, commercial and industrial establishments are now and then use to dispose wastes in roadsides, footpaths, open drains etc. This indicates improper management of the hazardous waste. Alam (2016) states that from the history human life the challenges of wastes are prevailing where every environmentalist, waste management practitioners opined that disposal of hazardous waste is also creating threat for environment and human life. Hence, the term solid waste management includes proper system of generation, storage, collection, treatment, transport, processing and disposal of wastes in compliance with the rules of health, economics and the other environmental impacts. Biswas et al (2008) narrates that the number of hospitals, clinics and diagnostic laboratories is enhancing greatly in Dhaka city which severely impacting in the balance of environment and harming the public health tremendously. As a result, the hazardous wastes of Health Care Establishments (HCE) are dumped into indiscriminately in the nearest open drain and garbage heap that cause both environmental and public health hazards. Daud et al (2014) opined that in Bangladesh like other developing countries the SWM is not up to the mark. Moreover, the issue of environmental protection is extremely ignored as a consequence of hazardous wastes. Nonetheless, various stakeholders like, the city authority, nongovernmental organizations (NGOs), Community based organizations (CBOs) and other private organizations are trying to manage solid waste together so that both nature and human life. Furthermore, almost 40$60 \%$ of wastes are not appropriately stored, collected and disposed due to shortcoming of motivation, awareness and commitment where Municipal Solid Wastes (MSW) are posing alarming result for the environmental society. Maseko (2014) states that in Tanzania the management of medical wastes and policies for protecting environment are outdated and showing fragmented approach. Consequently, the lacking of effective national policy for managing properly medical wastes in the developing countries are deteriorating and failed to enact appropriate legislation and guidelines for sustainable management of hazardous wastes. Jones (2016) explains that improper management of wastes cause severe environmental pollution where every wastes both hazardous and non hazardous pose threat to environment, human health and wildlife. Consequently, perils and hazards of public and nature become accelerated. Monjurul (2016) narrates that in Bangladesh the wastes management mechanisms are not completely well managed and those are not processed in an environment friendly way. Additionally, governmental roles in this regard are not effective rather some private companies and NGOs are trying to control negative impacts of hazardous wastes. UNEP report (2020b) states that Healthcare waste handlers are at the greatest risk during the COVID-19 pandemic. Provide necessary personal protective equipment for healthcare waste management workers, and inform and train them to use it for personal protection. UNEP Report (2020c) narrates that in fact, in this pandemic protection of human 
lives and recovery of livelihoods are becoming very much challenging by national and local policies and actions, proper management of waste, including of household, healthcare, and other hazardous waste, is an essential civic service to minimize possible secondary impacts upon health and the environment. UNEP Report (2020d) In pandemic of COVID-19 the collection of wastes is being severely hampered as measures of safety at work, secured handling of solid wastes where workers have risk of being infected by corona virus and more particularly securing and management of huge quantities of health care wastes of hospitals and clinics from collection to recycling or treatment in environmentally sound manner are in the challenging state. Consequently, the developing countries are facing threats of COVID-19 severely to prevent spread of infection and avert human and environmental hazards due to hazardous wastes during this pandemic. ADB Report (2020) states that due to pandemic of COVID 19 the generation of medical wastes have increased six time more than that of prepandemic period where it has been calculated in five of Southeast Asia's largest cities which saw infectious medical waste increase by 240 tonnes a day and the ADB estimated that Manila, Jakarta, Bangkok, Kuala Lumpur and Hanoi could be dealing with a total of 1,016 tonnes more medical waste per day. Razzak (2020b) states that in Dhaka, Bangladesh some NGOs are taking initiatives to collect and dispose medical wastes generated excessively during pandemic and medical waste are treated in Matuail landfill in Dhaka South City Corporation which is located $27 \mathrm{~km}$ far from Kuwait Bangladesh Friendship Hospital in Uttara, Dhaka. Hence, for being the treatment zone in more remoteness, the wastes are being thrown in a way which is hazardous to both human health and environment. Antara (2021b) states that survey of BRAC found in its survey titled "Effective Management of Medical Waste Amid Covid-19 Pandemic" that around 93.4\% of the Covid-19 related medical waste is not disposed of properly where $49.1 \%$ people stored the Covid-19 wastes in the same container along with other household wastes. As per the study it is mentioned by Dhaka North City Corporation (DNCC) Chief Waste Management Officer Commodore M Saidur Rahman that though the corporation does not have the capacity to provide a separate bag every day, the corporation instructed the residents to keep the Covid-19 waste separate. However, no one follows it. The UNEP COVID-19 Waste Management Factsheets (2020) outlined to mitigate the adverse impacts of the pandemic on global environment: from how to safely manage the increase of waste produced in response to the crisis, to how to control releases of harmful chemicals in the atmosphere, land and water.

\section{Environmental Perils due to Hazardous Waste Management}

A balanced state of environment is the part and parcel for the smooth leading of human life. There is strong link between sustainable and healthy management of hazardous wastes and conducive to environment. If wastes are not managed properly, then both human life and environment become endangered. Perfect treatment, storage, transportation, recycling and disposal of wastes might ensure a protected environment; otherwise, environment is hampered severely for mismanagement of various types of wastes. Misra and Pandey (2005a) stated that serious health impairment is caused due to environment contamination as a consequence of improper waste management practices. Moreover, though the risks of hazardous wastes cause detriment to human health, the most vulnerable situation arise because of environment pollution which is treated as the ultimate outcome of hazardous wastes. Hence, there is a great link between degradation environment and mismanagement of wastes and so improper treatment, storage, and disposal of hazardous wastes can result in contaminant during possible exposures, and potential adverse health and environmental 
impacts. Hasan (2005b) opined that imperfect system of solid waste brings both human health and environmental risk. Additionally, imperfect and ineffective hazardous waste management causes hazards of environment severely. Some remarkable aspects of environmental hazards are pointed out so that focused issues can be mitigated for protecting the environment from injurious results of hazardous wastes. Thus, improper management of wastes may cause major perils to the surface water, ground water, soil and air most particularly hampers the ecological balance of the environment, such as: a) Rampant solid wastes and open drains creates uncomfortable smell and perilous dust, b) Infectious diseases are spread because of insufficient and unhealthy disposal of wastes in the open dumps, c) Most of the industrial wastes in the Dhaka city are dumped into the river which pollutes both environment and river water very harmfully, d) When heavy metals are not treated properly rather thrown by the industries in open dumps which affect environment and also damage human health, e) When wastes from hospitals and clinics are dumped in bins without proper treatment which infect different diseases and cause lethal pollution, f) Sorting and recycling of wastes without proper protection by the waste pickers and scavengers might cause environmental perils and spread diseases. Hooghiemstra (2005) stated that effects of hazardous wastes can be controlled and mitigated by proper applications of legal frameworks of the environment protection, such as, Environment Conservation Act 1989 specially section 20 of the Act stated appropriate methods of disposing waste and provided responsibility of managing wastes to the specific company. Besides, the National Environmental Management Act 1998 emphasized on applying some principles i.e. duty of care: every organization has a duty to take care of wastes generated by it as a social responsibility, precautionary principle: this principle narrates that every wastes is hazardous and toxic and proper precaution must be endured to protect human health and environment from harmful impacts.

\section{International Legal Frameworks for Hazardous Waste Management}

In international environmental law and legal frameworks the issue of hazardous wastes is getting paramount significance as the issue directly pertinent to the protection of human heath as well as nature. Many developed countries have been successful in proper treatment and disposal of wastes in compliance with international legal standard of sound management of wastes. On the contrary the developing countries are considered as they not maintaining proper standard of protection due to shortcoming of information, non-existent of regulations and indifference to the compliance with international standards and legal frameworks. Hence, Legal arrangements for hazardous wastes are not sufficient in the developing countries. As environmentally sound management of hazardous wastes is essential to ensure proper health and natural resource management, some international legal and non-legal frameworks have been developed to mitigate toxic impacts of wastes. Those international provisions are being analyzed to know how they are playing roles in sound management of hazardous wastes:

a) Cairo Guide Lines 1985: Against illegal dumping of hazardous wastes in 1985 the Cairo guidelines were accepted where the main demand was to ensure environmentally sound management (ESM) of wastes. The guidelines include ability in the management of wastes by the persons involved, analyzing disposal plan's effectiveness, monitoring impacts on human health and environment. Hence, it can be summarized that the Cairo Guidelines were to focus administrative aspects of wastes management where the legal guidelines were not adequate to the waste management. 
b) Basel Convention 1989: The Basel Convention on the control of Trans-boundary Movement of Hazardous Wastes and their disposal, 1989 was framed to mitigate international trade in hazardous wastes where states were asked to maintain trans-boundary movement of wastes in compliance with environmentally sound management. The convention was held with three basic objectives: i) Reducing the generation of hazardous wastes in terms of quantity and hazardousness, ii) Disposing the wastes as close as their source of generation, iii) To control trans-boundary movement of goods. Moreover, the Basel convention imposes obligation to the states generating wastes to reduce to its minimum. The convention has given every state the right banning entry or disposal of foreign hazardous wastes in its territory. Furthermore, it importantly emphasized on the environmentally sound management of hazardous waste as stated there, "Taking all practicable steps to ensure that hazardous and other wastes are managed in a manner which will protect human health and environment against the adverse effects, which may result from such wastes." More significantly, article 4 of the convention states that it is general obligation of parties to minimize wastes generation and transboundary movement. However, it also ensured balance of conflicting interests of developed and less developed countries by stating that if there is to move minimum, there must be followed environmentally sound management system. Moreover, when any concerned state does not comply with obligations of convention, then the other involved state can refuse the agreement of trans-boundary movement of wastes. Additionally, as per s.4 (1) (b) of the convention if there is any state which prohibited import of wastes, at that time that state might not be allowed to export wastes ensure check and balance.

c) The 1999 Basel Protocol on Liability and Compensation: This Basel Protocol of 1999 narrates special legal obligations if there is any damages emerged from the trans-boundary movement of hazardous wastes. It established a comprehensive legal regime for sufficient and hasty compensation faced as a consequence of any illegal act without complying Basel Conventions. The aim of this protocol is to adjust the gap in Basel convention. The protocol highlighted the provision of damages by elaborate explanation i.e. loss of life or personal injury, loss of damage to property, loss of income, cost of impaired environment etc. Nonetheless, the protocol ensured some exemptions in some special circumstances i.e. during armed conflict, hostilities, civil war, insurrection or any wrongful conduct of third party.

d) 1992 Rio Declaration: United Nations Environment Programme (UNEP) is importantly materializing the provisions of hazardous wastes issue as narrated in Principle 10 of 1992 Rio declaration. It is stated in Principle 10 that "Environmental issues are best handled with participation of all concerned citizens, at the relevant level. At the national level, each individual shall have appropriate access to information concerning the environment that is held by public authorities, including information on hazardous materials and activities in their communities, and the opportunity to participate in decision-making processes." Thus, principle 10 of Rio Declaration establishes some significant rights, such as, access to information, access to public participation and access to justice. Here, access to information gives a citizen opportunity to take part actively in the making of decisions and policies, right to public participation refers to involvement of people in detecting environmental problems and encouraging government to attain sustainable development and finally, access to justice stands for enabling general people to get scope of seeking justice.

e) Agenda 21: Most of the chapters of Agenda 21 deal with hazardous wastes where chapters 20, 21 and 22 directly relevant to the provisions of the wastes issues. Chapter 20 of Agenda 21 emphasizes on environmentally sound management of hazardous wastes, including prevention of illegal individual and local Traffic in Hazardous Wastes. Thus, it states three 
significant aspects of hazardous wastes i.e. to narrate the importance of minimization of hazardous wastes, to accelerate the mechanism of hazardous wastes disposal and recycling and enhancing hazardous wastes education programs. Then chapter 21 of Agenda 21 describes specially on environmentally sound management of solid wastes and sewage related issues. This chapter mainly focuses on the reduction of wastes generation, developing strategies of wastes recycling and reusing, narrating environmentally sound waste disposal and treatment and finally, spreading wastes service coverage etc. Eventually, chapter 22 of Agenda 21 emphasizes on safe and sound management of radioactive wastes where it is stated with importance that developing administrative measures to materialize civilian radioactive waste management and disposal system, through education programs people are supposed to be aware in managing, transporting, storing and disposing radioactive wastes to protect human health and environment and initiating measures and enhancing ways to ensure an integrated approach of radioactive waste management.

f) The 1990 Code of Conduct on Radioactive Waste: It was a resolution adopted on 21 September 1990 in a general conference of International Atomic Energy Agency (IAEA) on Code of Practice on International Trans-boundary Movement of Radioactive Waste for establishing all essential measures to implement great dissemination of code of practice at both national and international level. This resolution established some guidelines and code of conduct which are appreciated by UN and all other international organization in international trans-boundary movement of radioactive wastes. It emphases on the responsibility of marking, packaging and labeling of radioactive wastes that ensures safety. Additionally, this established that carrier has responsibility for ensuring essential control mechanism during transport and storage of radioactive wastes.

g) The 1991 Bamako Convention: It is a convention on the Ban on the import into Africa and the Control of Trans-boundary Movement and Management of Hazardous Wastes within Africa. In 1991 this treaty was held by 12 nations of organization of African Unity at Bamako, Mali and came into force in 1998. The approach of Basel Convention has been promoted by the Bamako Convention which established national regime for prohibiting business relating to wastes trans-boundary movement. More significantly, there are some important aspects to be considered to compare between Basel and Bamako conventions, such as, a) both conventions forbid trade with regard to hazardous and radioactive wastes, b) Both conventions state that hazardous wastes to be exported or managed in environmentally sound manner, c) the concept of hazardous wastes is widely taken in Bamako convention than Basel convention, d) Bamako convention ensures that parties must coordinate with relevant government and non government organizations which lacks in Basel, e) Bamako narrates that products are supposed to be used as raw materials for recycling and recovery can't be exported.

\section{Existing National Legislations and Policies on Hazardous Waste Management}

In Bangladesh to have a sustainable management of Hazardous wastes the proper authority concerned initiated some remarkable measures in collaboration Japan International Corporation Agency (JICA). Additionally, UNICEP also commenced various effective programs. To manage overall situation the existing legal frameworks are supposed to review how they are working in Bangladesh. To analyze exact condition the existing laws and policies are examined below:

a) 3R (Reduce, Re-use and Recycle) Policy: In Bangladesh 3R policy is one remarkable ways of hazardous waste management. The concept has been started having cooperation with United 
Nations Centre for Regional Development (UNCRD) and Ministry of Environment of Government of Japan. Through this 3R policy of national waste management the country tried to reduce harmful impacts of wastes and ventured to accelerate the process of disposal of waste where recycling of wastes was also promoted to have success on the process. Nevertheless, the policies are applied successfully, some sectors were not properly under $3 R$ policy i.e. industry, commerce and production sector. Consequently, now it is also being thought by relevant experts that the $3 \mathrm{R}$ policy is supposed to be shifted to $5 \mathrm{R}$ policy i.e. Rethink, Reduce, Recycle, Recovery, and Re-use.

b) The Dhaka Municipal Ordinance 1983: For the very environmentally sound management of hazardous wastes the ordinance empowered the Dhaka City Corporation (DCC) to have collection and disposal of wastes, management on medical wastes and direction as to house scavenging, cleaning drainage and cleansing of streets etc. As per ordinance, the corporation shall conduct proper management of solid wastes of public streets, drains, dustbins where all garbage and refuse shall be collected under supervision by the staffs of corporation.

c) The Environment Policy, 1992: According to the Environment Policy 1992 the city corporation waste management is not allowed rather restricted to have disposal of wastes in any water bodies of ponds, rivers and drains. Additionally, the policy of 1992 prohibited strictly the carriage of wastes in garbage truck openly at day which might cause hazards to human health and environment i.e. air pollution.

d) The Penal Code, 1860: According to section 268 of the Penal Code, 1860 if there is held any public nuisance i.e. annoyance or detriment to public is committed in the management of wastes. At that time there is described penal provision in the criminal procedure. So, every negligent behavior that spread infectious disease and also shows negligence as to toxic materials, those will be regarded as crime in the eye of the Penal Code.

e) The Environment Conservation Rule, 1997: This conservation rules of 1997 declared some ecologically critical area of Bangladesh which are significant in the issue of environmental protection. Moreover, it categorized some environmental issues as green, orange and red category. Here, Landfill activity of hazardous wastes is also considered in red category where all industrial, household and commercial wastes will be managed as environment impact assessment. The special procedure of NOC (No objection Certificate) is supposed to be maintained.

f) Urban Management Policy Statement, 1998: This policy is applied in the municipalities to the disposal of solid waste including public sanitation, drain cleaning and road maintenance. The policy also conducts every endeavor to provide efficient services in the municipalities.

g ) The Factory Act, 1965: The Act mainly conducts its activities for cleanliness issues of the factory and industries specially in the corporation. The activities include disposal of wastes and liquids which are contaminated and also arrange the heavy traffic. Additionally, the Act also provide rules of services of drinking water, toilet specially in the mills and factories.

h) Special Directions of High Court: To protect as usual flow of Buriganga River , the High Court Division of Supreme Court of Bangladesh provided some directions to the concerned authority where issue was raised by a organization named 'Human Rights and Peace for Bangladesh.' In the direction, the court held that within one year all sewerage lines regarding waste treatment connected with the Buriganga. Consequently, the flow and beauty of Buriganga are under threat of extinction and So disposal and treatment of wastes in Buriganga were asked to stop within one year. Additionally, the Court also emphasized the DCC to raise awareness among the citizens and also display the placard of High Court's Directions should be attached for making the concerned authority mindful. 


\section{Modes of Applying Existing Legislations and Policy in Hazardous Waste Management}

The study makes it comprehensive that the sustainable management of hazardous waste is a crying need for the protection of human life as well as environment. To ensure environmentally sound management of hazardous waste the management needs to minimize production of hazardous wastes, to dispose wastes as close to the source of generation as possible, to control trans-boundary movement of hazardous wastes. From generation to the proper management of hazardous waste some effective methods are followed in the developing countries like, Bangladesh. The term generation of wastes means production of wastes. In Bangladesh the generation of waste is increasing year by year. As like as increment of per capita income the per capita wastes generation is also enhancing. Abedin and Jahiruddin (2015) state that with the growth of population the generation of solid wastes is also widening where 7690 tons of municipal solid waste (MSW) is generated daily in the major cities of Bangladesh i.e. Dhaka, Chattogram, Khulna, Rajshahi, Barishal and Sylhet. Moreover, for the assurance of sustainable hazardous waste some universally recognized methods are followed. Those methods are analyzed here with their effective situation in perspective of Bangladesh:

a) Collection of waste: Collection and storage is an effective means of waste management where hazardous wastes are collected from different pick up point. The collection crew with empty container collects wastes to treat them in environmentally sound manner. Singh et al (2014) state that the specific garbage truck by the corporation are managed to collect solid wastes from various residential points with a crew consisting of two or three people including driver. Moreover, typically every truck can collect 4 to 5 tons of wastes to the disposal sites per day. The frequency of solid waste collection in most communities is once or twice per week.

b) Transportation: Transportation is one of the critical methods of waste management where wastes are located in a particular place to recycle, treat, store or dispose the wastes. Transportation requires movement of wastes through roads, highways, rails and waterways. In this process, the hazardous waste is transported from the generating place to a place where wastes are recycled, treated, stored or disposed. In this process a treated hazardous waste is also moved from a site to another site for more treatment or disposal. Thus, in this transportation the city corporation authority collect wastes from secondary disposal site (SDS) and transfers to ultimate disposal site (UDS). In this case only motorized vehicles are used to apply the transportation method of hazardous waste management.

c) Waste minimization and Treatment: The term treatment of waste include modification of waste for making it suitable for disposal. Through the process of treatment wastes are minimized. The treatment technology includes neutralization, incineration, solidification which is used for the disposal of hazardous wastes. Those process are maintained properly so that no environmental hazards are caused. In addition, Misra and Pandey (2005b) state there is an urgent need for identification and assessment of abandoned hazardous waste disposal sites and remediation of the affected sites to prevent further damage to human health and environmental quality.

d) Dumping: The concept of dumping may be classified into two, such as, semi-controlled dumps and controlled dumps. In semi controlled dumps there are no engineering measures and informal waste picking is held. On the contrary, in controlled dumps there maintained proper placement of waste and monitoring of surface water is done.

e) Landfill: Landfill is one of the effective disposal methods of managing hazardous wastes. This form of waste management includes mixing of waste with soil, evaporation and 
infiltration and / or shallow burial. By the process of burial solid wastes are managed this is known mainly as landfill. Liquids, slurries and sludge might also be incorporated into a landfill. When landfills are kept in drums or plastic containers, they take very small quantities of hazardous wastes.

f) Burning: This is another method of managing MSW in environmentally sound manner where wastes are burned to reduce volume and odour of the dumped wastes. This process is mainly followed by most of the developing countries. This process also includes open burning of various toxic gases i.e. dioxins and furans etc.

g) Incineration: It is the process of waste disposal where solid materials are made capable of burning to non toxic gases which spread in the environment without any hazards. This is a very controlled process because if there is any negligence, then there may cause unwanted release of gas into atmosphere., Nandan et al (2017) state that sludge volume is reduced by incineration which turns into ash residue and it is so easy to manage for final disposal tempting to toxic soluble oxides of metal formation.

h) Composting: Composting is another form of environmentally sound management of hazardous wastes. It is also one kind of recycling. Through this process, soil like material is generated from MSW where a controlled biological decomposition of wastes is held. In different city corporation specially four large city corporations i.e. Dhaka, Chattogram, Khulna and Sylhet the composting methods are practiced specially by the NGOs. The NGOs are mainly related with the process of composting.

i) Recycling, Reuse and Reclamation: Recycling of wastes is most praiseworthy waste management mechanisms where wastes are turned into another source of productive use. By this process of reuse, recycling and reclamation the wastes are managed in environmentally sound manner and inadequate natural resources are protected appropriately. Moreover, the process of reuse and recycling are used in case of newspapers, metals, plastics and broken glasses which are collected from houses of the people. Besides, some wastes are collected by the street children from dustbins and containers which are reusable and recyclable. Those recycled plastics, glass, metals are used in various commercial purposes.

j) Energy recovery: The method of energy recovery from waste is also known as waste to energy (WTE) where non-recyclable waste is converted into useable heat and electricity by the process of combustion, gasification, anaerobic digestion and landfill gas recovery etc. Scarlat et al (2018) state that energy recovery as a significant means of waste management strategy which brought remarkable contribution in the renewable energy systems. The process of recovery of energy from MSW is also playing great role in the sector of renewable energy. Nowadays, this potential system of management of MSW is fully utilized through incineration with energy recovery.

k) Final disposal: In the final disposal process different vehicles i.e. truck and carriers take away the MSW to specific dumping area. For this purpose various heavy vehicles are also used by the authority i.e. Bull dodger, pay-loader excavator etc. In this disposal process mainly the wastes are disposed off in the lowland of the city which is situated in distant part of the city. Muyeed et al (2011) narrate that the uncollected wastes are dumped in open spaces, streets, clogs drainage system creating serious environmental degradation $\&$ health risks.

\section{Risks and Challenges Associated with Waste Management in COVID-19 Pandemic}

COVID-19 has had severe impact on every sector of human life and state including in waste management system. Indeed, many developed countries have enacted special guidelines to 
cope with the situation but developing countries are not being able to develop the special guidelines to face the challenges of COVID-19.Onogawa (2020) states that international organizations and academic associations have already issued guidelines for infectious waste management. However, many of those guidelines target both developed and developing countries and only a few guidelines are prepared specifically in response to the current condition of COVID-19 waste management in developing countries. Particularly, developing countries lack capacity in terms of financial, technical, social, and institutional aspects.

The challenges on the wastes management sector due to COVID-19 have been tremendously accelerated. Association of Cities and Regions for sustainable Resource management (2020) states that. When the pandemic was progressing and lockdowns imposed in many countries, public authorities and municipal waste operators had to rapidly adapt their waste management systems and procedures to the situation. Due to COVID-19 pandemic MSW collection frequency is changed and the assets are also redistributed for infectious medical waste management. ADB (2020) states that the process of hazardous waste management during COVID- 19 pandemic recycling activities should be avoided to remove human contact with infectious domestic and medical wastes. Special procedures for transport and disposal are supposed to be followed i.e. non-absorbent, sealed area capable of being locked, disinfected and separate from driver's cabin. And at the time of disposal, the process may vary from COVID-19 hospital and other hospitals. Yousefi et al (2021) states that the effects of COVID-19 on various wastes are not same as pandemic has reduced waste production in some areas and pervasively disrupted plastic consumption . It is estimated that 1.6 million tonnes / day globally plastic wastes are generated from the very beginning of COVID-19. Additionally, 3.4 million face masks and shields are discarded daily as single used.

\section{Findings of the Study}

After having a thorough study on the legal primary sources i.e. statutes, policies, conventions, declaration, resolutions, agenda, proclamations, conventions, and rules and decisions of court etc and secondary sources i.e. Law books, articles in book, journals, periodicals, treaties, decisions of the courts, legal dictionaries, digests, encyclopedia, internet sources etc on existing overall situation of hazardous waste management systems in the following findings are detected:

a) The management mechanisms are not properly adjusted with characteristics of the hazardous waste i. e. MSW, HCE wastes and radioactive wastes.

b) Not properly assessed the impacts of hazardous wastes on environment and heath to make people more concerned on the issue.

c) Not determining suitable location for sustainable management of waste by having consideration as to the danger of people, ecological balance and surface water resources.

d) Not application of best available technology (BAT) for managing different types of hazardous wastes including radioactive wastes.

e) Not arranging effective monitoring and workshop programs for providing compliance with national and international protection mechanism to pertinent stakeholders.

f) Not following proper packing, labeling and transporting systems for safe handling, storage, transportation and disposal practices of wastes.

g) Having shortcomings of adequate institutional arrangement for hazardous waste management.

h) Absence of application and compliance with national and international legislations and policies. 
i) Not having effective coordination between public, private and community groups to manage wastes properly.

j) Not maintaining proper and reliable records of total generation of the hazardous waste in Bangladesh.

k) Shortcoming of guidance, awareness, capacity building training on the management of hazardous waste.

I) No legislation of special Policy, regulatory and institutional framework for facing the challenges of COVID-19 pandemic.

$\mathrm{m})$ Not having coordinated monitoring authority how the legal frameworks are being applied.

n) During pandemic the developing countries like Bangladesh is facing extreme challenges in waste management because of technical and financial scarcity which is found as the most vulnerable condition.

o) Waste workers are not properly trained to mange highly contagious waste generated from COVID-19 treatment.

p) Lack of specialized Contagious COVID-19 waste mechanism system where COVID-19 waste requires to be burned at a minimum temperature of 1080 degree Celsius for disposal.

\section{Recommendations to Ensure Effective and Sustainable Hazardous Wastes Management Mechanisms}

The study reveals and points out some remarkable suggestions for establishing the purpose of the research and develops some recommendations for the betterment of the public health and environment protection. Those recommendations are mentioned below:

a) Conducting and enhancing awareness raising campaigns as to detrimental impacts of wastes on both human health and environment.

b) Providing technological and overall capacity building training to relevant stakeholders of the management of hazardous wastes.

c) Developing adequate institutional arrangement for environmentally sound management of hazardous waste.

d) Ensuring application and compliance of national and international legal framework for developing waste management systems.

e) Maintaining proper and reliable records of total generation of the hazardous waste in Bangladesh.

f) Regular monitoring mechanisms and evaluation of hazardous wastes management systems and confirming reporting on regular basis.

g) Strengthening and reforming existing regulatory frameworks.

h) Introduce training and education programmes for health care waste handlers during pandemic.

i) Establishing coordinated monitoring authority for checking application of legal national and international legal frameworks.

j) Determination of Key priority areas by governments and keeping focus on improving healthcare waste management to prevent the spread of COVID-19 is inevitable for Bangladesh.

k) Developing well trained healthcare waste management system by City Corporation and municipalities in collaboration with the Directorate General of Health Services to handle efficiently the most contagious wastes generated by pandemic.

I) Introducing national policies in compliance with the guidelines on monitoring and training on contagious COVID-19 waste management system developed by the UN agency. 


\section{Conclusion}

The challenges of increasing solid waste management are being more threatening day by day where effective application of policies and legislations is not being emphasized with utmost significance. Hence, both human and environmental perils are deteriorating. Additionally, shortcomings of technological skills and capacity building training for the relevant manpower of sustainable hazardous waste management in compliance with national and international guidance particularly with Basel Convention, 1989. The mechanisms and modes of sustainable waste management i.e. collection, transportation, treatment, recycling, landfill and final disposal of waste are supposed to be in environmentally sound manner so that scarce natural resources can stay safe and protected. Due to rapid urbanization and industrialization there is growth of population in the cities of Bangladesh particularly. Consequently, the rise of MSW in large quantities posing threats to the overall arrangements of hazardous wastes and Bangladesh is not out of some mentionable shortcomings, such as, inadequate economic support, lack of proper infrastructures and lack of well trained human resources for the purpose of sound waste management. More significantly, during COVID-19 pandemic the situation become more vulnerable and challenges of hazardous waste management have become more difficult to face as there is severe risk of being infected during collection of health care wastes specially.

\section{References}

Abedin, M. A., \& Jahiruddin, M. (2015). Waste generation and management in Bangladesh: An overview, Asian Journal of Medical and Biological Research ISSN 2411-4472 Retrieved from: www.ebupress.com/journal/ajmbr

ADB. (2020). Managing Infectious Medical Waste during the COVID-19 Pandemic., https://www.adb.org/ publications/managing-medical-waste-covid19

ADB Report. (2020). ADB: Coronavirus could leave major Southeast Asian cities with 1,000 extra tonnes of medical waste per day Eco-Business, Retrieved from: https://www. ecobusiness.com/news/adb-coronavirus-could-leavemajor-southeast-asian-cities-with1000-extra-tonnes-ofmedical-waste-per-day/

Akpon, V. E., \& Olukanni, D. O. (2020). Hazardous Waste Management: An African Overview, Recycling 2020, 5, 15; doi:10.3390/recycling5030015, Retrieved from: Recycling I An Open Access Journal from MDPI.

Alam, S. M. (2016). Strategic Institutional Capacity in Solid Waste Management, Academic Dissertation, University of Tampere School of Management, Finland.

Antara, F. N. (2021a). COVID-19 Medical Waste Disposal Neglected, The Dhaka Tribune, Retrieved from: www.dhakatribune.com/bangladesh/2021/04/11/covid-19-medicalwaste-disposal-neglected

Antara, F. N. (2021b). COVID-19 Medical Waste Disposal Neglected, The Dhaka Tribune, Retrieved from: www.dhakatribune.com/bangladesh/2021/04/11/covid-19-medicalwaste-disposal-neglected

Association of Cities and Regions for sustainable Resource management. (2020): Municipal waste management and COVID 19: Summary of observed trends (March 2020). Association of Cities and Regions. Retrieved from: https://www.acrplus.org/images/project/Covid-19/ ACR_2020_03_Waste_management_covid19_graph.jpg

Azad, A. K. (2017). An Incomplete List of Most Interesting Waste Management and Recycling Companies in Bangladesh, The Daily Star, Retrieved from: 
https://futurestartup.com/2017/12/09/incomplete-list-interesting-wastemanagement recycling-companies-bangladesh/

Biswas, T. K., Hassan, M. M., Ahmed, S. A., \& Rahman, K. A. (2008). Pattern of medical waste management: existing scenario in Dhaka City, Bangladesh, Retrieved from: http://www.biomedcentral.com/1471-2458/8/36

Callao, C., Nunez, M. M., \& Latorre, P. (2019). European Countries: Does common legislation guarantee better hazardous waste performance for European Union member states?, Retrieved from: https://doi.org/10.1016/j.wasman.2018.11.014 0956-053X/ 2018 Elsevier Ltd.

Daud, N. N., Rowshon, M. K., Shams, S., Sergany, M., \& Ahsan, A. (2014). Assessment of Municipal Solid Waste Management System in a Developing Country, Hindawi Publishing Corporation Chinese Journal of Engineering Volume 2014, Retrieved from: http://dx.doi.org/10.1155/2014/561935

Hasan, J. G. M. (2005a). Municipal Waste Management and Environmental Hazards in Bangladesh, Pakistan Journal of Biological Science, Retrieved from: DOI: 10.3923/pjbs.2005.921.928 · Source: DOAJ

Hasan, J. G. M. (2005b). Municipal Waste Management and Environmental Hazards in Bangladesh, Pakistan Journal of Biological Science, Retrieved from: DOI: 10.3923/pjbs.2005.921.928 · Source: DOAJ

Hooghiemstra, C. (2005). Delisting of Hazardous Waste Produced in a Tannery, Thesis of Master's in Environmental Management, Faculty of Science, University of Johannesburg.

Jones, M. W. (2016). Environmental management system optimization focusing on the waste environmental media in the chemical industry, A dissertation for the Degree of Doctor of Philosophy, Mississippi State University, Mississippi State, Mississippi.

Karthikeyan, L., Suresh, V. M., \& Krishan, V. (2018). The Management of Hazardous Solid Waste in India: An Overview, Retrieved from:

https://www.researchgate.net/publication/327518337_The_Management_of_Hazard ous_Solid_Waste_in_India_An_Overview

Khatib, A. I., Alsubu, M., Monou, M., \& Kassinos, D. (2009). Dental solid and hazardous waste management and safety practices in developing countries: Nablus district, Palestine, ISSN 0734-242X, Waste Management \& Research Los Angeles, London, New Delhi and Singapore. Retrieved from: http://www.sagepub.com.

Maseko, Q. (2014). Critical Evaluation of Medical Waste Management Policies, Processes and Practices in Selected Rural Hospitals in the Eastern Cape, A thesis of Master of Social Science in Environmental and Developmental Sociology of Rhodes University. Retrieved from: https://www.semanticscholar.org/paper/Critical-evaluation-of-medical-wastemanagement-and-Maseko/bdb1f300f14d77406e3c13d7ba8f5a3315492692

Misra, V., \& Pandey, S.D.(2005a). Hazardous waste, impact on health and environment for development of better waste management strategies in future in India, Retrieved from: Environment International - Journal - Elsevier.

Misra, V., \& Pandey, S.D.(2005b). Hazardous waste, impact on health and environment for development of better waste management strategies in future in India, Retrieved from: Environment International - Journal - Elsevier.

Monjurul, H. A. S. M. (2016). The biogas potential from municipal waste and agricultural residues in Hazaribagh, Dhaka city, Bangladesh, A Master's thesis, Department of Management and Engineering, Linkoping University. 
Muyeed, A. A., Talukder, A., Mazumdar, S., \& Shadullah, A.M.(2011). Solid Waste Management Practice in Dhaka City, Proceedings of the WasteSafe 2011 - 2nd International Conference on Solid Waste Management in the Developing Countries 1315 February 2011, Khulna, Bangladesh.

Nandan, A., Vani, S. V., Bhoumik, S., \& Siddiqui, N. A. (2017). Hazardous Waste - Impact on health and Environment for sustainable development in India, World Scientific News 70(2) (2017) 158-172, Retrieved from:

https://www.researchgate.net/publication/31996462

Olukanni, D. O., \& Oresanya, O. O. (2018). Progression in Waste Management Processes in Lagos State, Nigeria, international Journal of Engineering Research in Africa - March 2018 Retrieved from: https://www.researchgate.net/publication/324118809

Onogawa, K. (2020), Waste Management during the COVID-19 Pandemic, United Nations Environment Programme, International Environmental Technology Centre (IETC), IGES Center Collaborating with UNEP on Environmental Technologies (CCET).

Rahman, M. M. (2014). Developing the Waste Management System in Dhaka City, Bangladesh, Thesis of Business School, Degree programme in International Busines, Seinajoki University of Applied Sciences.

Razzak, M. A. (2020a). Can Bangladesh Cope With COVID-19 medical waste?, The Daily Star, Retrieved from: www.thedailystar.net/opinion/news/can-bangladesh-cope-covid-19medical-waste-1897327

Razzak, M. A. (2020b). Can Bangladesh Cope With COVID-19 medical waste?, The Daily Star, Retrieved from: www.thedailystar.net/opinion/news/can-bangladesh-cope-covid-19medical-waste-1897327

Sawalem, M., Selic, E., \& Herbell, J. D. (2008). Hospital waste management in Libya: A case study, Retrieved from: https://files.transtutors.com/cdn/uploadassignments/781059_2_casestudy-risk.pdf

Scarlat, N., Fahl, F., \& Dallemand, J. F. (2018). Status and Opportunities for Energy Recovery from Municipal Solid Waste in Europe, Waste and Biomass Valorization (2019) 10:24252444, Retrieved from: https://doi.org/10.1007/s12649-018-0297-7

Singh, G. K., Gupta, K., \& Chaudhary, S. (2014). Solid Waste Management: Its Sources, Collection, Transportation and Recycling, International Journal of Environmental Science and Development, Vol. 5, No. 4, August 2014.

Tania, F. (2014). Solid Waste Management of Dhaka City: A Socio-Economic Analysis, Banglavision, Vol. 13, No. 1, 2014, pp 94-94

UNEP COVID-19 Factsheets (2020). COVID-19 Waste management Factsheets, Retrieved from:https://www.unep.org/resources/factsheet/covid-19-waste-managementfactsheets

UNEP report. (2020a). Waste Management during the COVID-19 Pandemic, From Response to Recovery, Retrieved from:

https://reliefweb.int/sites/reliefweb.int/files/resources/WMC-19.pdf

UNEP report. (2020b). Waste Management during the COVID-19 Pandemic, From Response to Recovery, Retrieved from:

https://reliefweb.int/sites/reliefweb.int/files/resources/WMC-19.pdf

UNEP report. (2020c). Waste Management during the COVID-19 Pandemic, From Response to Recovery, Retrieved from:

https://reliefweb.int/sites/reliefweb.int/files/resources/WMC-19.pdf 
UNEP report. (2020d). Waste Management during the COVID-19 Pandemic, From Response to Recovery, Retrieved from: https://reliefweb.int/sites/reliefweb.int/files/resources/WMC-19.pdf

Yousefi, M. , Osoei, V., Jafari, A. J., Farzadkia, M., \& Firooz, M. H. (2021). Municipal solid waste management during COVID-19 pandemic: effects and repercussions, Retrieved from: doi: 10.1007/s11356-021-14214-9 [Epub ahead of print].

Hossain, M. I., San, O. T., Ling, S. M., Said, R. M., \& Teh. B. H. (2021). Nexus of Stakeholder Integration, Environmental Investment, Green Technology Adoption and Environmental Sustainability Practices: Evidence from Bangladesh Textile SMEs. Journal of Social Sciences and Humanities. [On press]

Hossain, M. I., San, O. T., Tabash, M.I., Ling, S. M., Said, R. M. (2021). Systematic Review: Identifying Drivers of Environmental Sustainability Practices in Small and Medium Sized Enterprises (SMEs). International Journal of Sustainable Economy. [On press]

Hossain, M. I., San, O. T., Ling, S. M., \& Said, R. M. (2020). The Role of Environmental Awareness and Green Technological Usage to Foster Sustainable Green Practices in Bangladeshi Manufacturing SMEs. International Journal of Advanced Science and Technology. 29 (7s), 3115-3124.

Hossain, M. I., Polas , M. R. H., Rahman, M. M., Islam, T., \& Jamadar, Y. (2020). An Exploration of COVID-19 Pandemic and its Consequences on FMCG Industry in Bangladesh. Journal of Management Info, 7(3), 145-155. https://doi.org/10.31580/jmi.v7i3.1484 